\title{
Pengaruh terapi oksigen hiperbarik terhadap penyembuhan luka pada luka bakar derajat dua dalam pada hewan coba kelinci
}

\author{
${ }^{1}$ Rudy H. Susilo, ${ }^{2}$ Mendy Hatibie, ${ }^{3}$ Jan T. Ngantung, ${ }^{4}$ Meilany F. Durry \\ ${ }^{1}$ Program Studi Ilmu Bedah Fakultas Kedokteran Universitas Sam Ratulangi Manado \\ ${ }^{2}$ KSM Ilmu Bedah RSUP Prof. Dr. R. D. Kandou Manado \\ ${ }^{3}$ Bagian Ilmu Bedah Fakultas Kedokteran Universitas Sam Ratulangi Manado \\ ${ }^{4}$ Bagian Patologi Anatomi Fakultas Kedokteran Universitas Sam Ratulangi Manado \\ Email: dr.rudyhs@yahoo.com
}

\begin{abstract}
Wound healing process consists of inflammation, proliferation, and remodelling phases with increasing inflammatory cells, angiogenesis, and epithelization. Mechanism of hyperbaric oxygen therapy is $\mathrm{O}_{2}$ pressure over 1 ATA will increase oxygen pressure in the tissue. The main outcome measure is wound healing. This study was aimed to obtain the influence of hyperbaric oxygen therapy to wound healing process of deep second degree burn wounds. This was an experimental study. Subject were 36 rabbits divided into 2 groups, each of 18 rabbits. Deep second degree burn wounds were performed on all rabbits. One group was treated with hyperbaric oxygen therapy 2.4 ATA for 6 days, meanwhile the other group as control. The result of Mann-Whitney $U$ test showed significant differences in inflammatory cells $(P=0.025)$ and epithelization $(P=0.024)$; albeit, there was not significant difference in angiogenesis $(P=0.442)$ between the two groups. Conclusion: Hyperbaric oxygen therapy could influence the inflammatory cells and epithelization but not the angiogenesis.
\end{abstract}

Keywords: second degree burn wound, healing process, hyperbaric oxygen therapy

\begin{abstract}
Abstrak: Proses penyembuhan luka terdiri dari: fase inflamasi, proliferasi, dan perupaan kembali/remodeling, yang tampak dengan meningkatnya sel-sel radang, angiogenesis serta epitelialisasi. Mekanisme kerja terapi oksigen hiperbarik (TOHB) ialah pemberian tekanan $\mathrm{O}_{2}$ yang melebihi 1 ATA akan menyebabkan peningkatan tekanan $\mathrm{O}_{2}$ dalam jaringan. Jenis penelitian ialah eksperimental. Subyek penelitian 36 ekor kelinci yang dibuat luka bakar derajat dua dalam, kemudian dibagi menjadi dua kelompok, masing-masing 18 ekor. Kelompok perlakuan diberikan TOHB dengan dosis 2,4 ATA selama 6 hari sedangkan kelompok lain sebagai kontrol. Hasil uji Mann-Whitney U menunjukkan terdapat perbedaan bermakna pada jumlah sel radang $(P=0,025)$ dan epitelialisasi $(P=0,024)$, tetapi tidak terdapat perbedaan bermakna pada angiogenesis $(\mathrm{p}=0,442)$, serta ada perbedaan bermakna pada pada kedua kelompok. Simpulan: Terapi oksigen hiperbarik berpengaruh terhadap jumlah sel radang dan epitelialisasi namun tidak terhadap angiogenesis.
\end{abstract}

Kata kunci: penyembuhan luka bakar, oksigen hiperbarik, luka bakar derajat dua dalam

Luka bakar adalah salah satu kondisi yang dapat mematikan dan masih merupakan masalah kesehatan utama. Penanganan dan perawatan luka bakar (khususnya luka bakar berat) memerlukan perawatan yang kompleks dan masih merupakan tantangan tersendiri karena angka morbiditas dan mortalitas yang cukup tinggi. Di Amerika dilaporkan sekitar 2-3 juta penderita setiap tahunnya dengan jumlah kematian sekitar 5-6 ribu kematian per tahun. ${ }^{1}$ Di Indonesia, data dari Unit Luka Bakar RSCM pada periode Januari 2011-Desember 2012, tercatat 275 pasien dirawat akibat luka 
bakar; 203 diantaranya usia dewasa dengan angka mortalitas $27,6 \%$. Terdapat $78 \%$ kasus luka bakar disebabkan oleh api, dengan derajat luka bakar grade II sampai grade III. ${ }^{2}$ Di RSUP Prof. Dr. R. D. Kandou, Manado selama tahun 2014 tercatat 85 kasus luka bakar yang dirawat di bangsal bedah, dan menempati urutan ke-6 dari 10 kasus terbanyak di bangsal bedah. ${ }^{3}$ Kematian umumnya terjadi pada 7 hari pertama masa perawatan (masalah jangka pendek) sedangkan sisa kasus yang bertahan hidup menghadapi masalah tersendiri, antara lain lamanya masa perawatan yang berkisar antara 4-14 hari hari rawat dan penyulit yang timbul (masalah jangka panjang). ${ }^{1}$

Terapi luka bakar diarahkan pada tujuan untuk meminimalkan edema, mempertahankan jaringan yang sehat pada zona stasis, melindungi mikrovaskularisasi, meningkatkan daya tahan host, dan menyediakan substrat yang diperlukan untuk mempertahankan viabilitas jaringan. Tujuan utama dari terapi luka bakar mencakup kelangsungan hidup pasien, kecepatan peyembuhan luka, meminimalkan scar atau pigmentasi yang abnormal, dan efektifitas biaya pengobatan. Hasil optimal yang diharapkan ialah pemulihan kualitas hidup sedapat mungkin seperti keadaan sebelum menderita luka bakar., ${ }^{4,5}$

Paradigma penatalaksanaan luka bakar mengalami perubahan seiring dengan perkembangan ilmu pengetahuan dalam bidang kedokteran khususnya bidang biomolekuler dan traumatologi. Permasalahan yang dihadapi memerlukan pendekatan beberapa displin ilmu yang mutlak secara terpadu bersama-sama mengupayakan penurunan angka mortalitas dan morbiditas luka bakar. ${ }^{6}$

Penggunaan oksigen bertekanan tinggi sudah dikenal sejak 1662. Pada tahun 1917, Drager berhasil memanfaatkan terapi oksigen hiperbarik (TOHB) untuk decompresion sickness, dan selanjutnya secara lambat laun mulai berkembang. Pada tahun 1960-an Boerema meneliti penggunaan TOHB yang larut secara fisik di dalam darah, sehingga dapat memberi hidup pada keadaan tanpa hemoglobin yang disebut life without blood. ${ }^{7,8}$ Dewasa ini TOHB telah banyak dimanfaatkan, diantaranya untuk penderita luka bakar, decompresion sickness, osteomielitis, dan ulkus/gangren diabetikum. ${ }^{9}$

Mekanisme kerja TOHB ialah dengan tekanan $\mathrm{O}_{2}$ yang melebihi dari satu atmosfer akan menyebabkan peningkatan tekanan $\mathrm{O}_{2}$ pada jaringan sehingga gradien difusi oksigen ke dalam jaringan akan meningkat. Selain itu oksigen dapat larut ke dalam cairan darah secara fisika sehingga turut membantu membawa oksigen ke daerah yang mengalami hipoksia. Oksigen yang larut tersebut akan keluar ke ekstra vaskuler dan ruang intrasel dengan cara difusi dan kemudian digunakan oleh sel, meningkatkan metabolisme enzimatik dalam sel sehingga aktifitas penyembuhan luka akan meningkat. ${ }^{10,11}$

Bilic et al. $^{5}$ melakukan penelitian mengenai pemberian TOHB pada tikus dengan luka bakar derajat II dan menyimpulkan bahwa TOHB memiliki keuntungan terhadap penyem-buhan luka bakar. Penelitian oleh Cianci et al. ${ }^{4}$ melaporkan data dari beberapa studi penelitian yang dilakukan baik terhadap manusia maupun hewan mengenai penggunaan TOHB pada luka bakar dengan hasil nyata dan konsisten dalam mencegah iskemik pada kulit, mengurangi edema, memodulasi zona stasis, mencegah penambahan kerusakan derajat luka bakar, memelihara metabolisme selular, dan memicu penyembuhan.

RSUP Prof. Dr. R. D. Kandou telah memiliki hyperbaric chamber room sejak Oktober 1995, tetapi umumnya hanya sering digunakan untuk pasien dengan decompression sickness. Tujuan penelitian ini ialah untuk mengetahui pengaruh pemberian terapi oksigen hiperbarik (TOHB) pada proses penyembuhan luka bakar derajat dua dalam pada hewan coba kelinci, yang dinilai dengan parameter jumlah sel radang, angiogenesis, dan epitelialisasi. 


\section{METODE PENELITIAN}

Jenis penelitian ini ialah eksperimental pada hewan percobaan kelinci. Penelitian ini dilaksanakan pada bulan Agustus sampai Desember 2015. Subyek penelitian ialah 36 ekor kelinci ternak jantan yang memenuhi kriteria inklusi, dikarantina agar dapat beradaptasi. Setelah selesai masa karantina, dibuat luka bakar derajat dua dalam, berukuran $2 \times 1 \mathrm{~cm}$ pada masingmasing punggung kelinci, dan semua luka dioles dengan Biocream ${ }^{\circledR}$ kemudian kelinci dibagi menjadi dua kelompok, masingmasing 18 ekor. Kelompok A mendapat perlakuan TOHB yang dimulai dalam 24 jam pertama, dengan dosis 2,4 ATA (atmosfer absolut) selama 6 hari berturutturut, dengan masing-masing sesi 90 menit, sedangkan kelompok B tidak mendapat perlakuan TOHB, sebagai kontrol. Pada hari ke-14 semua kelinci dieutanasia dan jaringan luka bakar dieksisi, kemudian dikirim ke Laboratorium Patologi Anatomi FK Unsrat Manado untuk evaluasi histopatologik.

\section{HASIL PENELITIAN}

Hasil pemeriksaan histopatologik, proses penyembuhan luka dinilai dengan parameter jumlah sel radang, angiogenesis, dan proses epitelialisasi (Tabel 1). Hasil uji kenormalan data dengan uji KolmogorovSmirnov menunjukkan data jumlah sel radang pada kelompok $\mathrm{A}$, angiogenesis pada kelompok A dan B, serta epitelialisasi pada kelompok A dan B tidak menyebar normal (Tabel 2); oleh sebab itu uji perbedaan kedua kelompok digunakan uji Mann-Whitney U.

Tabel 1. Statistik jumlah sel radang, angiogenesis, dan proses epitelialisasi pada kedua kelompok

\begin{tabular}{llccc}
\hline Kelompok & Jumlah sel radang & Angiogeneis & Epitelialisasi \\
\hline $\mathrm{A}$ & $\mathrm{N}$ & 18 & 18 & 18 \\
& Minimum & 70 & 8 & 10 \\
& Maximum & 1200 & 50 & 80 \\
& Median & 175,00 & 10,00 & 10,00 \\
& Mean & 340,00 & 25,78 & 28,61 \\
& Std. Deviation & 317,953 & 18,985 & 22,739 \\
\hline B & N & 18 & 18 & 18 \\
& Minimum & 70 & 8 & 5 \\
& Maximum & 950 & 50 & 60 \\
& Median & 550,00 & 27,50 & 10,00 \\
& Mean & 516,67 & 27,33 & 14,17 \\
& Std. Deviation & 273,195 & 18,156 & 13,201 \\
\hline
\end{tabular}

Tabel 2. Uji kenormalan data

\begin{tabular}{lcccc}
\hline Variabel & & \multicolumn{3}{c}{ Kolmogorov-Smirnov } \\
\cline { 3 - 5 } & Kelompok & Statistik & $\mathrm{db}$ & $\mathrm{p}$ \\
\hline Jumlah sel radang & $\mathrm{A}$ &, 281 & 18 &, 001 \\
\cline { 2 - 5 } Angiogenesis & $\mathrm{B}$ &, 132 & 18 &, 200 \\
\multirow{2}{*}{ Epitel } & $\mathrm{A}$ &, 353 & 18 &, 000 \\
& $\mathrm{~B}$ &, 275 & 18 &, 001 \\
& $\mathrm{~A}$ &, 349 & 18 &, 000 \\
\hline
\end{tabular}

$\mathrm{db}=$ derajat bebas 


\section{Perbedaan jumlah sel radang}

Dari hasil uji statistik terhadap perbedaan jumlah sel radang pada kelompok yang mendapat perlakuan TOHB dan kontrol dapat disimpulkan bahwa terdapat perbedaan bermakna antara kedua kelompok $(P=0,025)$ (Tabel 3).

Tabel 3. Hasil uji pengaruh TOHB pada jumlah sel radang

\begin{tabular}{lccc}
\hline Kelompok & $\begin{array}{c}\text { Mean } \\
\text { rank }\end{array}$ & $\begin{array}{c}\text { Mann- } \\
\text { Whitney } \\
\text { U test }\end{array}$ & $\boldsymbol{P}$ \\
\hline $\mathrm{A}(\mathrm{TOHB})$ & 15,06 & 100,000 & 0,025 \\
$\mathrm{~B}$ (kontrol) & 21,94 & & \\
\hline
\end{tabular}

\section{Perbedaan angiogenesis}

Dari hasil uji statistik perbedaan angiogenesis kelompok yang mendapat perlakuan TOHB dan kontrol dapat disimpulkan bahwa tidak terdapat perbedaan bermakna antara kedua kelompok $(P=0,442)$ (Tabel 4).

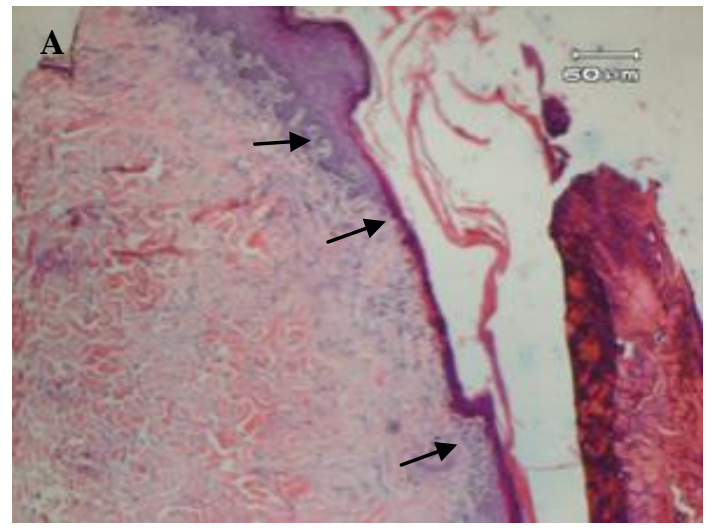

Gambar 1. Perbandingan secara mikroskopik proses epitelialisasi antara kelompok dengan TOHB (A) dan kontrol (B). Anak panah menunjukkan epitelisasi

\section{BAHASAN}

Luka bakar merupakan salah satu jenis luka yang dapat didefinisikan sebagai rusaknya sebagian jaringan tubuh akibat terpapar benda atau sesuatu yang panas, zat kimia, dan sengatan listrik. ${ }^{12}$ Luka bakar dapat mengenai lapisan epidermis atau dermis bahkan jaringan subkutan. Tingkat kedalaman luka bakar ini sangat ditentukan

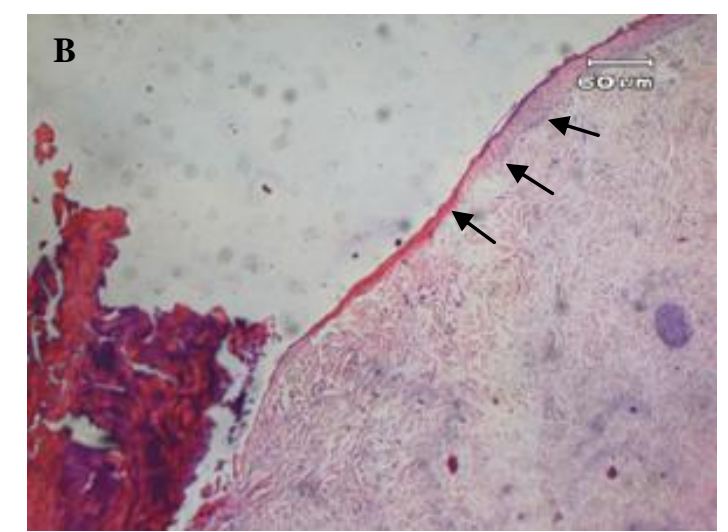

Tabel 4. Hasil uji pengaruh TOHB pada angiogenesis

\begin{tabular}{cccc}
\hline Kelompok & $\begin{array}{c}\text { Mean } \\
\text { rank }\end{array}$ & $\begin{array}{c}\text { Mann- } \\
\text { Whitney } \\
\text { U Test }\end{array}$ & $\boldsymbol{P}$ \\
\hline A (TOHB) & 18,75 & 157,500 & 0,442 \\
B (kontrol) & 18,25 & & \\
\hline
\end{tabular}

\section{Perbedaan proses epitelialisasi}

Dari hasil uji statistik perbedaan proses epitelialisasi pada kelompok yang mendapat perlakuan TOHB dan kontrol dapat disimpulkan terdapat perbedaan bermakna antara kedua kelompok $(P=$ 0,024 ) (Tabel 5).

Tabel 5. Hasil uji pengaruh TOHB pada proses epitelialisasi

\begin{tabular}{lccc}
\hline Kelompok & $\begin{array}{c}\text { Mean } \\
\text { rank }\end{array}$ & $\begin{array}{c}\text { Mann- } \\
\text { Whitney } \\
\text { U test }\end{array}$ & $\boldsymbol{P}$ \\
\hline $\mathrm{A}(\mathrm{TOHB})$ & 21,83 & 102,00 & 0,024 \\
$\mathrm{~B}$ (kontrol) & 15,17 & & \\
\hline
\end{tabular}


kelangsungan hidup sel-sel yang berbatasan dengan daerah cedera. Hambatan sirkulasi pada jaringan di bawah daerah cedera mengakibatkan luka menjadi kurang kelembabannya yang dapat menghambat proses penyembuhan luka secara alami. ${ }^{4}$

Pemberian TOHB pada luka bakar memiliki mekanisme kerja yaitu tekanan $\mathrm{O}_{2}$ yang melebihi 1 atmosfer akan menyebabkan peningkatan tekanan $\mathrm{O}_{2}$ pada jaringan, sehingga gradien difusi oksigen ke dalam jaringan akan meningkat. Selain itu, oksigen dapat larut dalam cairan plasma darah secara fisika yamg turut membantu membawa oksigen ke daerah yang mengalami hipoksia. Oksigen yang larut tersebut akan keluar ke ekstravaskuler dan ruang intrasel dengan cara difusi dan kemudian digunakan oleh sel yang selanjutnya akan meningkatkan metabolisme enzimatik intrasel dan aktifitas penyembuhan luka akan meningkat. ${ }^{4,16,17}$ Cianci et al. ${ }^{4}$ pada tahun 2013 melaporkan data dari beberapa studi penelitian yang dilakukan terhadap manusia maupun hewan mengenai penggunaan TOHB pada luka bakar dengan hasil yang nyata dan konsisten dalam perlangsungan proses penyembuhan luka, yaitu antara lain mencegah iskemi pada kulit, mengurangi edema, memodulasi zona stasis, mencegah penambahan kerusakan derajat luka bakar, memelihara metabolisme selular, dan selanjutnya mempercepat penyembuhan.

Hasil analisis data untuk menilai adanya pengaruh TOHB terhadap proses penyembuhan luka pada luka bakar derajat dua dalam dengan menggunakan parameter jumlah sel radang, angiogenesis, dan epitelialisasi pada kedua kelompok, mendapatkan perbedaan bermakna pada jumlah sel radang antara kedua kelompok $(P=0,025)$. Kelompok dengan TOHB secara histologik memperlihatkan jumlah sel radang (rerata 340) lebih sedikit dibandingkan kelompok kontrol (rerata 516,67). Menurut acuan pustaka, pada luka bakar terjadi perubahan respon imunologik yang mencakup perubahan fungsi makrofag dan gangguan imunitas baik seluler maupun humoral. Terjadi kerusakan mikrosirkulasi lokal sampai batas terluas selama 12-24 jam pasca luka bakar. Periode dinamis ini dapat terjadi sampai 72 jam setelah cedera yang kemudian secara cepat diikuti dengan iskemi dan nekrosis. Edema merupakan ciri yang paling menonjol, dan cepat terjadi pada daerah cedera sebagai akibat peningkatan permeabilitas kapiler, penurunan tekanan onkotik, peningkatan tekanan onkotik interstitial, perubahan pada ruang interstisial, dan kerusakan sitem limfatik. Proses progresif ini dapat berkembang secara drastis selama hari-hari pertama setelah cedera. Kerusakan yang sedang berlangsung pada cedera termal terjadi karena beberapa faktor, termasuk kegagalan jaringan sekitar menyediakan oksigen dan nutrien untuk mempertahankan kelangsungan hidup sel-sel yang berbatasan dengan cedera. Hambatan sirkulasi pada jaringan di bawah cedera karena edema mengganggu kelembaban luka karena cairan tidak dapat melalui kapiler yang mengalami trombus dan obstruksi Netrofil merupakan sumber utama dari oksidan dan cedera dalam mekanisme iskemia/ reperfusi. ${ }^{4}$

Terapi oksigen hiperbarik (TOHB) dapat meningkatkan jumlah oksigen yang terlarut dalam darah, hal ini menyebabkan peningkatan oksigen yang dilepaskan pada daerah yang terlibat di sirkulasi plasma darah sehingga dapat mengurangi hipoperfusi pada daerah luka yang mengalami edema dan vasokonstriksi. ${ }^{18}$ Hasil penelitian Nylander et al. ${ }^{19}$ terhadap hewan coba menjelaskan bahwa TOHB menurunkan edema yang disebabkan oleh luka bakar. Kaiser et al. juga memperlihatkan penurunan yang sama dari edema subkutan pada hewan coba dengan luka bakar yang diberi TOHB, dan melaporkan bahwa pada hewan coba kontrol, ukuran luka bakar terus bertambah sedangkan pada hewan coba yang diberikan TOHB ukuran luka berkurang. ${ }^{5}$ Hammarlund et al. ${ }^{20}$ menjelaskan bahwa TOHB menurunkan pembentukan edema. Beberapa peneliti lain menjelaskan penurunan pembentukan edema pada hewan coba yang diberi TOHB. Dalam hal ini penurunan edema 
berhubungan tidak hanya dengan penurunan aliran darah dan perfusi kapiler tetapi juga karena mempertahankan metabolisme aerobik yang berperan penting dalam integritas mikrovaskular. Penurunan pembentukan edema kemungkinan merupakan hasil mempertahankan integritas mikrovaskular dan oksigen yang diberikan pada TOHB diperlukan untuk mempertahankan kelangsungan hidup seluler. ${ }^{5}$

Pada penelitian ini jumlah sel radang yang lebih sedikit pada kelompok dengan perlakuan TOHB berhubungan dengan pengaruh TOHB untuk menurunkan pembentukan edema, sehingga mikro sirkulasi serta perfusi di tingkat seluler tetap terjaga, dan kerusakan jaringan akibat iskemi yang disebabkan oleh netrofil sebagai agen utama oksidan dan cedera sel dalam mekanisme iskemik seluler dapat ditekan. Hal ini mendukung penelitian yang dilakukan oleh Thom et al. ${ }^{21}$ yang menjelaskan bahwa TOHB pada 2,8 atau 3,0 ATA dapat menghambat beta 2 integrin dependent yang terikat dengan netrofil. ${ }^{5}$ Dosis TOHB yang digunakan pada penelitian ini yaitu 2,4 ATA lebih sedikit dibandingkan pada penelitian yang dilakukan oleh Thom et al. ${ }^{21}$ tetapi ternyata cukup memberikan pengaruh bermakna terhadap penurunan jumlah sel radang. Hal ini dapat memberikan peluang untuk penelitian lanjutan agar mendapatkan nilai cut of point dari dosis TOHB yang cukup untuk memberikan pengaruh bermakna terhadap jumlah sel radang.

Pada penelitian ini, untuk angiogenesis tidak terdapat perbedaan bermakna antara kelompok perlakuan TOHB dan kontrol $(P$ $=0,442)$. Hasil ini berbeda dari acuan pustaka oleh Bilic et al. ${ }^{5}$ yang meneliti pengaruh TOHB terhadap luka bakar pada mencit, dan mendapatkan angiogenesis yang cukup tinggi dibandingkan kontrol. Hasil penelitian ini sejalan dengan penelitian yang dilakukan Nikijuluw et al. ${ }^{22}$ mengenai pengaruh TOHB terhadap penyembuhan luka primer fraktur dengan intramedulary nail pada hewan coba kelinci, dan hasil yang didapat menunjukkan tidak terdapat perbedaan bermakna dalam hal angiogenesis. Kemungkinan penyebab hasil yang berbeda pada penelitian ini ialah secara konseptual proses penyembuhan luka terdiri dari fase inflamasi, fase proliferasi, dan fase perupaan kembali/remodelling. Proses angiogenesis terjadi pada fase proliferasi yang dimulai dari hari ke-5 cedera dan berlangsung sampai minggu ke-3. Sampel kulit pada penelitian ini diambil pada hari ke-14 dimana fase proliferasi masih berlangsung, sehingga sangat dimungkinkan pada saat pengambilan sampel, proses angiogenesis masih berlangsung. Karena faktor tersebut maka data yang didapat pada penelitian ini menyatakan tidak terdapat perbedaan bermakna antara kedua kelompok. Disarankan untuk dapat dilakukan penelitian lanjutan mengenai pengaruh TOHB pada angiogenesis dan sampel diambil pada saat fase proliferasi telah selesai. Di sisi lain, hasil yang didapat ini mendukung pernyataan dari Boerema yaitu penggunaan TOHB dapat memberi hidup pada keadaan tanpa hemoglobin yang disebut life without blood. ${ }^{8,9}$

Pada proses epitelialisasi didapatkan adanya perbedaan bermakna antara kelompok perlakuan TOHB dan kelompok kontrol $(P=0,024)$. Rerata proses epitelialisasi pada tiap luka dengan perlakuan TOHB mencapai $28,61 \%$, sedangkan pada kontrol hanya $14,17 \%$ (Gambar 1).

Epitelialisasi merupakan kejadian yang paling penting dalam proses penyembuhan luka bakar derajat dua dalam karena epitelialisasi merupakan penanda akhirnya stadium awal penyembuhan. Ada beberapa kemungkinan, bagaimana TOHB dapat memengaruhi proses epitelialisasi luka bakar derajat dua, pertama TOHB dapat membantu meminimalkan pengaruh merusak setelah luka bakar dan membiarkan jaringan hidup untuk membentuk permukaan luka, yang kedua dapat meningkatkan kecepatan mitotik sel sub epitelial atau dapat mempercepat migrasi sel epitel sehingga mempercepat penyembuhan.

Korn et al. ${ }^{23}$ memperlihatkan bahwa 
luka bakar derajat dua mengalami penyembuhan lebih cepat bila diterapi dengan TOHB Penelitian ini menjelaskan bahwa jaringan epitel dapat bertahan tanpa oksigen, tetapi sel tidak dapat membelah atau bermigrasi. Oksigen yang cukup di dalam jaringan, membuat sel epitel dapat bermigrasi dan membelah merupakan hal yang sangat penting untuk penyembuhan luka.

Epitelialisasi tergantung pada jumlah total populasi sel yang bertahan pada awal jaringan mengalami cedera, serta kemampuan mitosis dan migrasi sel. TOHB pada penelitian ini mempengaruhi proses ini dengan meminimalkan luasnya kerusakan luka dan meningkatkan oksigenasi pada jaringan yang mengalami hipoksia, di mana pada sel yang mengalami cedera termal pada umumnya tidak dapat bertahan. Penelitian ini memperlihatkan proses epitelialisasi yang lebih cepat pada kelompok yang mendapat perlakuan TOHB dibandingkan dengan kelompok kontrol, yang mendukung teori bahwa level oksigen yang adekuat merupakan hal yang mutlak untuk penyembuhan luka.

Dari hasil penelitian ini maka dapat disimpulkan bahwa TOHB memberikan pengaruh yang baik terhadap proses penyembuhan luka pada luka bakar derajat dua dalam yang dilakukan pada hewan coba kelinci, terutama pada jumlah sel radang dan proses epitelialisasi. Hal ini sesuai dengan teori dari mekanisme kerja oksigen hiperbarik yaitu dengan tekanan $\mathrm{O}_{2}$ yang melebihi dari 1 atmosfer akan menyebabkan peningkatan tekanan $\mathrm{O}_{2}$ pada jaringan, sehingga gradien difusi oksigen ke dalam jaringan akan meningkat. Selain itu oksigen dapat larut ke dalam cairan plasma darah secara fisika sehingga turut membantu membawa oksigen ke daerah yang mengalami hipoksia. Oksigen yang larut tersebut akan keluar ke ekstra vaskuler dan ruang intra seluler dengan cara difusi dan kemudian digunakan oleh sel. Selanjutnya akan meningkatkan metabolisme enzimatik dalam sel dan aktifitas penyembuhan luka akan meningkat. 4,16,17

\section{SIMPULAN}

Berdasarkan hasil penelitian ini, maka dapat disimpulkan bahwa penggunaan TOHB menurunkan jumlah sel radang dan mempercepat proses epitelisasi namun tidak berpengaruh terhadap angiogenesis. Secara keseluruhan, pemberian TOHB dapat mempercepat proses penyembuhan luka bakar derajat dua dalam pada hewan coba kelinci.

\section{SARAN}

1. Penelitian ini dapat menjadi bahan referensi ilmiah untuk melakukan penelitian lebih lanjut pada manusia dalam hal pengaruh TOHB terhadap penyembuhan luka bakar.

2. Dapat dilakukan penelitian lanjutan dengan menggunakan parameter, modalitas, serta metode penelitian yang lain untuk melihat pengaruh TOHB pada proses penyembuhan luka bakar.

\section{DAFTAR PUSTAKA}

1. Moenadjat RY. Luka Bakar Pengetahuan Klinis Praktis (1st ed). Jakarta: Farmedia, 2000.

2. Martina NR, Wardhana A. Mortality analysis of adult burn patients. Jurnal Plastik Rekonstruksi. 2013; p.96. www.jprjournal.com

3. Data 10 penyakit terbanyak ruang rawat inap bedah RSUP Prof. Dr. R.D. Kandou, Manado tahun 2014

4. Cianci P, Slade JB, Sato RM, Faulkner J. Adjunctive hyperbaric oxygen therapy in the treament of thermal burns. Undersea Hyperb Med. 2013;40(1):89-108

5. Bilic I, Petri NM, Bezic J, Alfirevic D, Modun D, Capkun V, et al. Effects of hyperbaric oxygen therapy on experimental burn wound healing in rats: A randomized controlled study. UHM. 2005;32(1-Hyperbaric Oxygen and Burn Wound Healing in Rats

6. Moenadjat RY. Petunjuk Praktis Penatalaksanaan Luka Bakar. Jakarta: Asosiasi Luka Bakar Indonesia, 2005.

7. Kawasima $M$, Tamura $H$, Nagayoshi I, Takao K, Yoshida K, Yamaguchi T. Hyperbaric oxygen therapy in 
orthopedic conditions. Undersea Hyperb Med. 2004;31(1):155-62.

8. Kot J, Desola J, Simao AG, Gough-Allen R, Houman R, Meliet J-L, et al. A European code of good practice for HBO therapy. Prepared by the working group Safety of the COST action B14 Hyperbaric Oxygen Therapy, May 2004.

9. Chris DL, Caroline O. Hyperbaric oxygen therapy: A rapid assesment. KCE report vol 74. Belgia, 2008

10. Origani G, Michael M, Amrroni A. Physiology and physiopathology of hyperbaric oxygen. In: Oriani G, Marroni A, Wattel F, editors. Handbook on Hyperbaric Medicine. Italia: Springer, 1996; p. 1-34.

11. Tibbes PM, Edelsberg J. Hyperbaric oxygen therapy. NEJM. 1996;334(25):1642-7.

12. Perdanakusuma DS. Skin grafting. Surabaya: Airlangga University Press, 1998; p. 3-9.

13. Sudjatmiko G. Luka bakar: Petunjuk Praktis Ilmu Bedah Plastik Rekonstruksi (1st ed). Jakarta: Yayasan Khasanah Kebajikan, 2007; p. 80-2.

14. Friedstat J, Endorf FW, Gibran NS. Burns. In: Schwartz's Principle of Surgery (10th ed). New York: Mc Graw-Hill, 2015; p. 227-9.

15. Brown DL, Burscel GH. Burns. In: Michigan Manual of Plastic Surgery (1st ed). Philadelphia: Lippincott Williams \& Wilkins, 2004; p. 381-2.

16. Sahni T, Singh P, John MJ. Hyperbaric oxygen therapy: Current trends and applications. JAPI. 2008;51:280-4.

17. Delaney JS, Montgomery DL. How can hyperbaric oxygen contribute to treatment? Phys Sportsmed. 2001;29(3):1-8.

18. Gill AL, Bell CNA. Hyperbaric oxygen: its use, mechanism of action, and outcomes. QJ Med. 2004;97:385-95.

19. Nylander G, Lewis $D$, Nordstrom $H$, Larsson J. Reduction of postischemic edema with hyperbaric oxygen. Plast Reconstr Surg. 1985;76(4):596-603.

20. Hammarlund C, Sundberg. Hyperbaric oxygen reduced size of chronic leg ulcers: a radomized double-blind study. Plast Reconstr Surg. 1994;93(4):82933.

21. Thom SR. Hyperbaric oxygen - its mechanisms and efficacy. Plast reconstr Surg. 2011;127(Suppl 1):131S-141S.

22. Nikijuluw R, Noersasongko $D$, Sunaryo H, Moningka A. Pengaruh terapi oksigen hiperbarik pada penyembuhan primer fraktur dengan intramedullary nail (pada hewan coba kelinci) [Karya akhir]. Manado: Universitas Sam Ratulangi; 2011.

23. Korn HN, Wheeler ES, Miller TA. Effect of hyperbaric oxygen on second-degree burn woound healing. Arch Surg. 1977;112(6):732-7. 